\title{
Analysis of physicochemical and sensory parameters of wine produced from Carica papaya
}

\author{
Suhail Cholassery ${ }^{1}$, Vidhu Krishna ${ }^{1}$, SreethuVeliparambil Sethuraj ${ }^{1}$,Shabnam Shajahan Rehina ${ }^{1}$, Vandana Ranganathan ${ }^{1}$, Lisha \\ Chanassery Dileep ${ }^{1}$, Kuzhunellil Raghavanpillai Sabu², Bhama Ramachandran Rajesh ${ }^{1}$, Ramachandran Pratap Chandran ${ }^{1 *}$ \\ ${ }^{1}$ Department of Biotechnology and Research, K. V. M. College of Science and Technology, Cherthala, India \\ ${ }^{2}$ Department of Chemistry, Arba Minch University, Arba Minch, Ethiopia
}

\section{ARTICLE INFO \\ Article history: \\ Received on: February 13, 2019 \\ Accepted on: June 28, 2019 \\ Available online: September 10, 2019}

\section{Key words:}

Fermentation, papaya, reducing sugar, Saccharomyces cerevisiae, wine

\begin{abstract}
Wine is one of the most ancient beverages and it consists of a complex mixture of alcohol, sugars, aldehydes, tannins, pectins, vitamins, minerals, and organic acids formed by the action of Saccharomyces cerevisiae on fruit juices. Papaya (Carica papaya) is a common plant originally from South America and grown mainly in Asian and African countries. In the present study, C. papaya fruit pulp was used for the production of wine under controlled fermentation using S. cerevisiae. The physicochemical parameters such as $\mathrm{pH}$, yeast cell count, specific gravity, carotenoid content, and alcohol content were observed during the study. The analysis was done once every 5 days. Fourier Transform Infrared Spectroscopy analyses of wine and unfermented fruit juice samples also were carried out. During fermentation, the $\mathrm{pH}$ was changed from 5.1 to 4.4. The initial value of yeast cell count during the fermentation process was $8.5 \times 10^{6} \mathrm{cells} / \mathrm{ml}$, later it attained the maximum value of $9.53 \times 10^{6}$ cells per $\mathrm{ml}$ on the 5 th day. It then gradually decreased to a final value of $2.92 \times 10^{6} \mathrm{cells} / \mathrm{ml}$ on the 20th day. The specific gravity was initially 1.1573 and it decreased to 1.1483 . Carotenoid content was 0.034 $\mathrm{mg} / \mathrm{ml}$ on the first day and it increased to $0.279 \mathrm{mg} / \mathrm{ml}$. Alcohol content of papaya was found to be increased during the course of fermentation. It was estimated as $3.01 \%$ on the 5 th day and it increased to $10.11 \%$ on the 20th day. The overall point for the sensory analysis was 4.8 .
\end{abstract}

\section{INTRODUCTION}

Papayas, also known as papaws or pawpaws grow in tropical climates. They are sweet in taste and have a vibrant color. They provide a wide variety of health benefits which make them a popular fruit that includes reducing the risk of diabetes, cancer, heart attack, improving blood sugar regulation in diabetics, lowering blood pressure, aiding wound healing, and improving digestion. It is a fruit growing in a polygamous herbaceous plant and bears fruits throughout the year in a good tropical climate. The fruit remains in clusters near leaves, and after maturation and ripening, the fruits turn yellow or red. It has a high sugar content of $59 \%$. Papaya fruit is a nutrient dense food and is rich in many vitamins, phytonutrients, and minerals. In contrast with different fruits like banana, guava, and apples, papaya has a lot

*Corresponding Author

R. Pratap Chandran, Department of Biotechnology and Research

K. V. M. College of Science and Technology, Cherthala, India.

E-mail:drpratapchandran@yahoo.co.in more carotenes which facilitate the reduction of oxidative stress [1]. Papaya wine is also regarded as a promising nutraceutical and an effective antioxidant [2].

Wine is a fermented drink made by the controlled culture of yeasts on fruit juices. The fermentation can be induced by yeast pure cultures like baker's yeast or by using natural $S$. cerevisiae strains. Wine as a beverage assumes a vital place in human life, including in spiritual, economic, and societal contexts [3]. This is a comparatively less energy intensive preservation method to increase the period of expiry and to avoid maintaining at low temperatures or using other techniques for preservation [4]. The yeast strains used also have a great influence on the overall quality of the wine [5]. In the present study, papaya fruit pulp was used for the production of wine using $S$. cerevisiae, and the physicochemical and sensory evaluation of papaya wine was also carried out. 


\section{MATERIALS AND METHODS}

\subsection{Collection of Fruit}

About $2 \mathrm{~kg}$ of ripe papaya was collected from the local fruits market Cherthala, Alappuzha, Kerala, India. Once it was brought to the laboratory, it was thoroughly rinsed with the running tap water, peeled, diced, and macerated to yield $1.6 \mathrm{~kg}$ of pulp.

\subsection{Yeast Strain}

Yeast strain $S$. cerevisiae was obtained from the stock cultures maintained at the microbiology research lab at KVM College, Cherthala. This was revived and then used for wine-making.

\subsection{Revival of Yeast and Preparation of Inoculum}

The yeast strains were cultured in $1 \%$ glucose yeast extract sterile broth, overnight at room temperature on table top shaker set at $60 \mathrm{rpm}$. To separate the cells, the culture broth was centrifuged at $6000 \mathrm{rpm}$ for 10 minutes at $4^{\circ} \mathrm{C}$. The cells were suspended in normal saline buffer to a density of $10^{8}$ cells $\mathrm{ml}^{-1}$ to prepare the pre-inoculum, after washing twice. From this mixture, $10 \mathrm{ml}$ was taken and mixed with $100 \mathrm{ml}$ of papaya fruit juice in a $250 \mathrm{ml}$ Erlenmeyer flask to prepare the inoculum. This was incubated at room temperature on a table top shaker set at $60 \mathrm{rpm}$.

\subsection{Preparation of Must}

To prepare the must solution, $1 \mathrm{~kg}$ of sugar and 11 of water were added to previously prepared $1.6 \mathrm{~kg}$ of papaya pulp in a 5-1 wine flask. This mixture was autoclaved at $121^{\circ} \mathrm{C}$ for a duration of 20 minutes to sterilize it, before allowing it to cool. To start the fermentation, the revived yeast culture with active wine yeast was added to the must and mixed thoroughly. A control solution was also prepared in a separate Erlenmeyer flask similarly without the addition of yeast.

\subsection{Fermentation}

The wine flask was allowed to ferment at room temperature in a cool dark environment for 20 days. At an interval of every 5 days, aliquots were drawn from the fermentation flask and control flasks by siphoning with sterilized tubes through layers of muslin cloth. To carry out the assortment of analytical tests, these filtrates were used. After 20 days, the wine flask was immersed in $70{ }^{\circ} \mathrm{C}-$ $80^{\circ} \mathrm{C}$ water bath to stop the fermentation. The wine was filtered as before and the sensory evaluation was carried out.

\subsection{Determination of Yeast Cell Count}

Optical density (OD) is a widely used method to estimate the number of cells in culture. Yeast cell count was determined by using a spectrophotometer. The sample was taken in the cuvette and the OD was measured against the control at $600 \mathrm{~nm}$. The optical density of yeast cells at $600 \mathrm{~nm}$ is around $10^{7}$ cells per $\mathrm{ml}$ and the value was estimated accordingly [6].

\subsection{Determination of $\mathbf{p H}$}

A digital pH meter (Eutech Cyber Scan pH 510) calibrated with standard buffers ( $\mathrm{pH} 4$ and 7) was used to measure the $\mathrm{pH}[6] .10 \mathrm{ml}$ of the sample was taken and the $\mathrm{pH}$ was determined using the digital $\mathrm{pH}$ meter to measure the trend.

\subsection{Measurement of Temperature}

The temperature was measured by laboratory mercury thermometer inserted through sealed sterile rubber cork into the fermentation flask. The temperature changes during the course of fermentation were recorded periodically.

\subsection{Determination of Relative Density}

The relative density was determined using specific gravity bottle [7]. The specific gravity bottle $(50 \mathrm{ml})$ was washed thoroughly using distilled water. It was then placed under hot air oven and then allowed to cool. The weight of dried bottle was measured to obtain $W 1$. Distilled water was then filled in the bottle and the excess water on the outside was blotted with filter paper before weighing. This value was recorded as $W 2$. After emptying bottle, the sample was filled up to the brim of the bottle and weighed to obtain $W 3$. To calculate the relative density, the following equation was used:

$$
\text { Relative Density }=\frac{W_{3}-W_{1}}{W_{2}-W_{1}}
$$

\subsection{Determination of Alcohol Content}

Alcohol content was determined using the iodoform method. Iodoform reacts with alcohol and is oxidized to aldehydes (primary alcohol) and ketones (secondary alcohol). The paleyellow precipitate of iodoform thus formed is equivalent to the alcohol present in the sample. Here, four drops of $1 \mathrm{~N}$ Sodium hydroxide was added to a test tube containing $1 \mathrm{ml}$ of sample. To this, concentrated iodine solution was dripped until a light yellow color persisted. This was then incubated for a minute at room temperature. If excess color appeared, an excess sodium hydroxide solution was used. To settle the yellow precipitate, the tubes were allowed to stand for a couple of minutes. This was then removed and the mass of precipitate was measured to determine the alcohol content.

\subsection{Estimation of Total Carotenoid Content}

Total carotenoid content was estimated using the method of Harborne [8]. Here, $10 \mathrm{ml}$ of wine sample was collected and filtered to yield $100 \mathrm{mg}$ solids. One hundred milligrams of these filtered wine solids were taken with $10 \mathrm{ml}$ of $80 \%$ acetone in a mortar and pestle and ground well. This was then centrifuged at 3,000 rpm for 10 minutes. The supernatant was taken and the pellet discarded. The supernatant was made up to a known volume of $10 \mathrm{ml}$. Then read the OD at $480 \mathrm{~nm}$ in a spectrophotometer (Systronics 117).

$\begin{aligned} & \text { Amount of carotenoids } \\ & \text { in } 100 \mathrm{mg} \text { wine solids }\end{aligned}=4 \times$ OD Value $\times \frac{\text { Total volume of sample }(10 \mathrm{ml})}{\text { Weight of fresh plant tissue }(100 \mathrm{mg})}$

\subsection{FTIR Analysis}

The wine sample and control was retrieved and Fourier Transform Infrared Spectroscopy (FTIR) spectroscopy was done. FTIR is a versatile tool to analyze compounds, identify the various functional groups, and detect the bonds between them. The spectrum displays the specific light wavelengths absorbed by chemical bonds which can characterize them. Thus, various chemical bonds present 
in a molecule can be analyzed through the interpretation of the obtained infrared spectrum. A wine sample drop was mixed with potassium bromide $(1: 100 \mathrm{p} / \mathrm{p})$ in agate mortars to prepare the tablets for FTIR spectroscopy (FTIR Shimadzu Prestige 21). The absorption spectra in the range of $400-4000 \mathrm{~cm}^{-1}$ were measured.

\subsection{Organoleptic Evaluation}

The organoleptic traits such as flavor, taste, odor, clarity, and the overall acceptance of the sample were evaluated on the 20th day [9]. A group of panellist of 20 individuals was selected and was asked to rate odor, color, clarity, and taste on a five points scale (Excellent quality_Five points and Poor Quality_One point).

\section{RESULTS AND DISCUSSION}

Wines are unprocessed alcoholic alimentary beverages typically made from fruits such as grapes, banana, peaches, etc. The fruit juices endure through a process of aging after the action of yeasts which leads to a major change in the composition and flavor [10]. Besides ethanol, most wines contain different types of aldehydes, sugars, tannins, esters vitamins, minerals, and other flavoring compounds [11]. The $\mathrm{pH}$ of different fruit wines will be different [12]. The $\mathrm{pH}$ of the unfermented must in the present study was 5.10 and it gradually decreased to 4.45 during the course of fermentation. The decrease in $\mathrm{pH}$ indicates an increase in acidity. The yeast cell count during the fermentation process was measured using a spectrophotometer and initial value was found to be $8.5 \times 10^{6}$ cells $\mathrm{ml}^{-1}$. Then it attained the maximum value of $9.53 \times 10^{6}$ cells $\mathrm{ml}^{-1}$ on the 5th day and it then gradually decreased to a final value of $2.92 \times$ $10^{6}$ cells $\mathrm{ml}^{-1}$ on the 20 th day. Initially, the yeast cell count showed an increase but as the fermentation proceeded, it decreased. The initial specific gravity obtained was $1.1573 \mathrm{~g} \mathrm{~cm}^{-3}$. It then decreased and reached a value of $1.1465 \mathrm{~g} \mathrm{~cm}^{-3}$ on the 20th day. The values of $\mathrm{pH}$, yeast cell count, and specific gravity were shown in Table 1 .

The results were in agreement with the reports of Satav and Pethe [13]. The acidic $\mathrm{pH}$, however, favors the increased production of alcohols. A probable cause for this might be growth inhibition of other microorganisms at acidic $\mathrm{pH}$, leading toward increased alcohol production by yeasts [13]. Acidity has a crucial role in dictating the quality of the wine by regulating fermentation, improving the balance and overall characteristic traits of wine. The absence of acidity will certainly diminish the fermentation and will lead to a poor product [14]. The temperature also showed variations during fermentation. It may be because of the changes that occur during

Table 1: Physicochemical parameters of papaya wine during regular intervals.

\begin{tabular}{lccccc}
$\begin{array}{l}\text { Physicochemical } \\
\text { parameters }\end{array}$ & $\mathbf{0}$ & $\mathbf{5}$ & $\mathbf{1 0}$ & $\mathbf{1 5}$ & $\mathbf{2 0}$ \\
$\mathrm{pH}$ & 5.10 & 4.95 & 4.78 & 4.63 & 4.45 \\
& $\mathrm{Nil}$ & $9.53 \times 10^{6}$ & $6.87 \times 10^{6}$ & $3.32 \times 10^{6}$ & $2.92 \times 10^{6}$ \\
$\begin{array}{l}\text { Yeast viable cell count } \\
\left(\text { cells ml }{ }^{-1}\right)\end{array}$ & 1.1573 & 1.1549 & 1.1504 & 1.1483 & 1.1465 \\
$\begin{array}{l}\text { Specific gravity } \\
\left.(\mathrm{g} \mathrm{cm})^{-3}\right)\end{array}$ & & & & & \\
& 25 & 25 & 26 & 28 & 30 \\
Temperature $\left({ }^{\circ} \mathrm{C}\right)$ & & & & & \\
\hline
\end{tabular}

utilization of the substrate by the yeast. The alcohol content increased during the course of fermentation and it also added to the quality of the wine. The Fusel alcohols (higher alcohols) have been noted as key molecules for the synthesis of fragrant esters [15]. The flavor obtained was as a result of fermentation and there was no need for any additional flavor enhancers. Previous studies have indicated that the action of yeasts during fermentation might lead to the formation of other by-products besides ethyl alcohol. These include acetyls, carbonyls, esters, and other alcohols [16]. $\beta$-carotene is the chief carotenoid with pro-vitamin A action, among the several constituents of $C$. papaya fruits [17]. The carotenoid content increased as days passed. The initial value obtained was $0.034 \mathrm{mg} / \mathrm{ml}$. On the final day (Day 20), the value increased to $0.279 \mathrm{mg} / \mathrm{ml}$ (Fig. 1). The initial specific gravity of the wine was 1.1573 and it gradually decreased to 1.1465 during the fermentation process. After the aging of wine, the sensory evaluation was done. The parameters included were color, odor, taste, and flavor. The overall point obtained was 4.8 out of 5 . FTIR analysis was also done to find the components present in the wine. It gives an account of the functional groups.

\subsection{FTIR Analysis}

The unfermented papaya fruit pulp contains plenty of carbohydrates as evidenced from absorption bands between 900 and $1,400 \mathrm{~cm}^{-1}$. The region corresponding to $900-1,153 \mathrm{~cm}^{-1}$ represents $\mathrm{C}-\mathrm{O}$ and

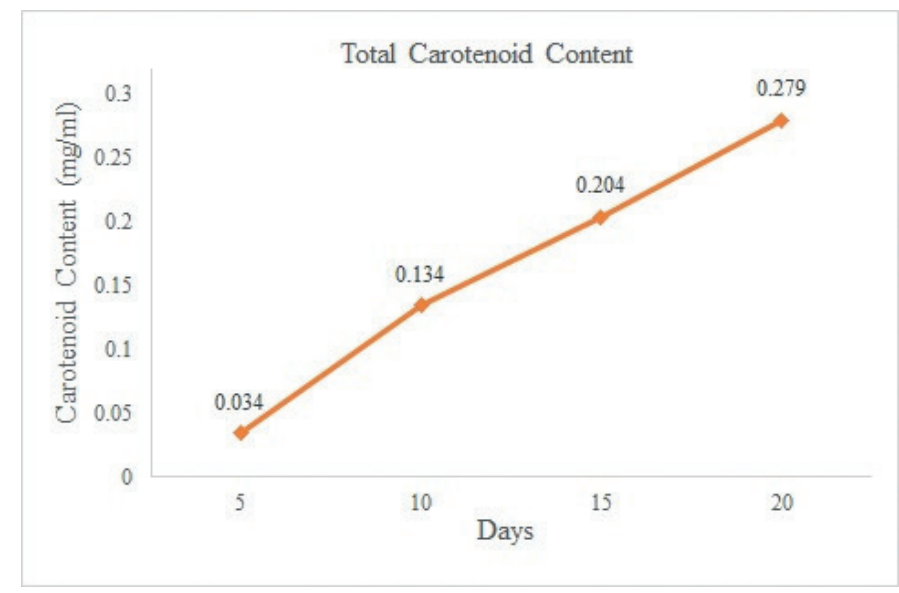

Figure 1: Graph showing the carotenoid content during regular intervals.

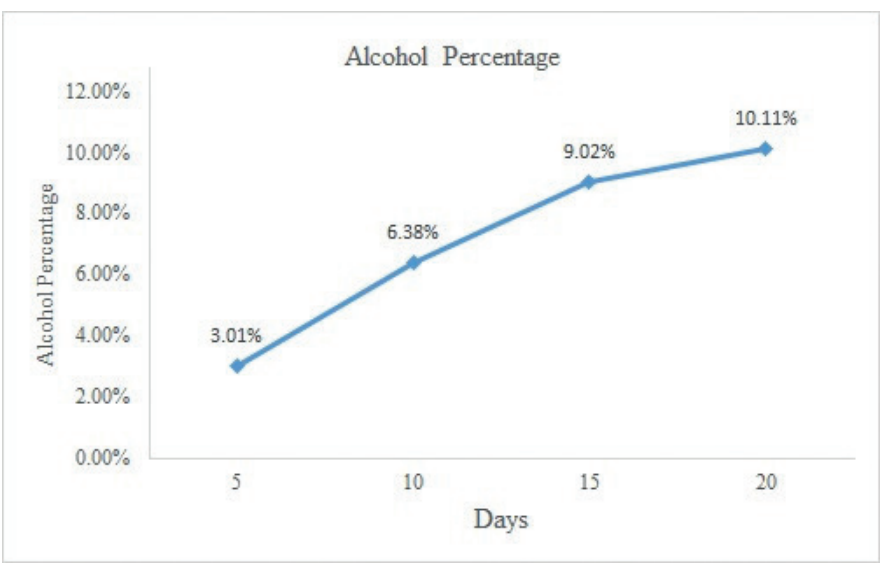

Figure 2: Graph showing the alcohol content during regular intervals. 
C-C stretching modes and those peaks particularly appearing between 119 and $1,415 \mathrm{~cm}^{-1}$ correspond to O-C-H, C-C-H, and $\mathrm{C}-\mathrm{O}-\mathrm{H}$ bending vibrational modes of carbohydrates. Also, the marker band of sucrose is well evidenced at $993 \mathrm{~cm}^{-1}$. The broader bands between 3,100 and $3,400 \mathrm{~cm}^{-1}$ correspond to $-\mathrm{OH}$ stretching vibrations and the absorptions between 2,800 and $3,000 \mathrm{~cm}^{-1}$ indicate $\mathrm{C}-\mathrm{H}$ stretching modes of simple or complex carbohydrates. Hydroxyl groups from moisture and traces of alcohols also would have contributed to these absorption peaks.

On the other hand, the spectrum of fermented papaya fruit sample shows that there occurred a complete conversion of sucrose to ethyl alcohol as characterized by the disappearance of the marker band of sucrose at $995 \mathrm{~cm}^{-1}$. Simultaneously there appeared a sharp and intense absorption band at $1,060 \mathrm{~cm}^{-1}$ due to the C-O stretch of ethanol and the $\mathrm{C}-\mathrm{H}$ stretch of ethyl group is evidenced at $2,936 \mathrm{~cm}^{-1}$. Some absorption peaks due to unfermented glucose and fructose are visible between 900 and $1,400 \mathrm{~cm}^{-1}$. The broader peaks at $3,371 \mathrm{~cm}^{-1}$ could be due to the $-\mathrm{OH}$ stretching vibrations of alcohol and also due to the presence of moisture. FTIR analysis was performed and $\mathrm{OH}$ group was detected. The results obtained are given in Figures 3 and 4.

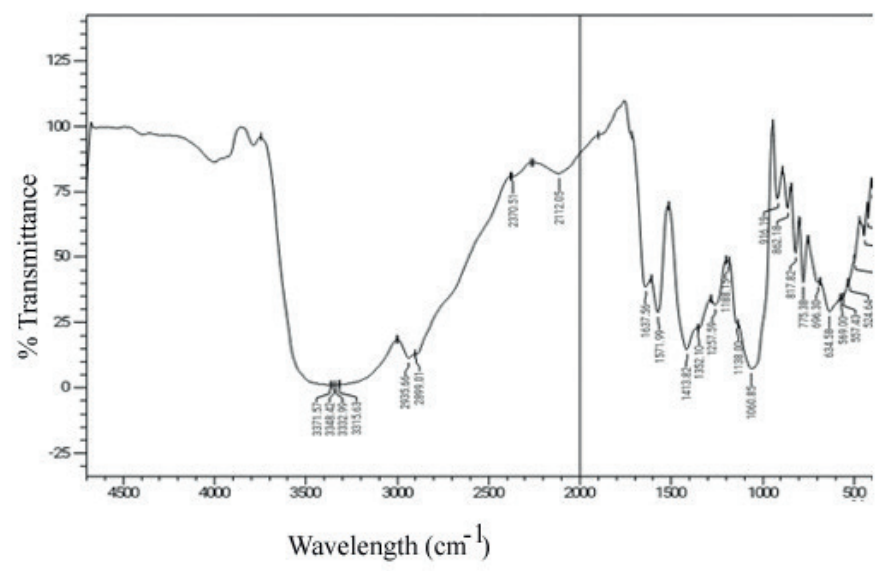

Figure 3: FTIR of fermented papaya fruit pulp.

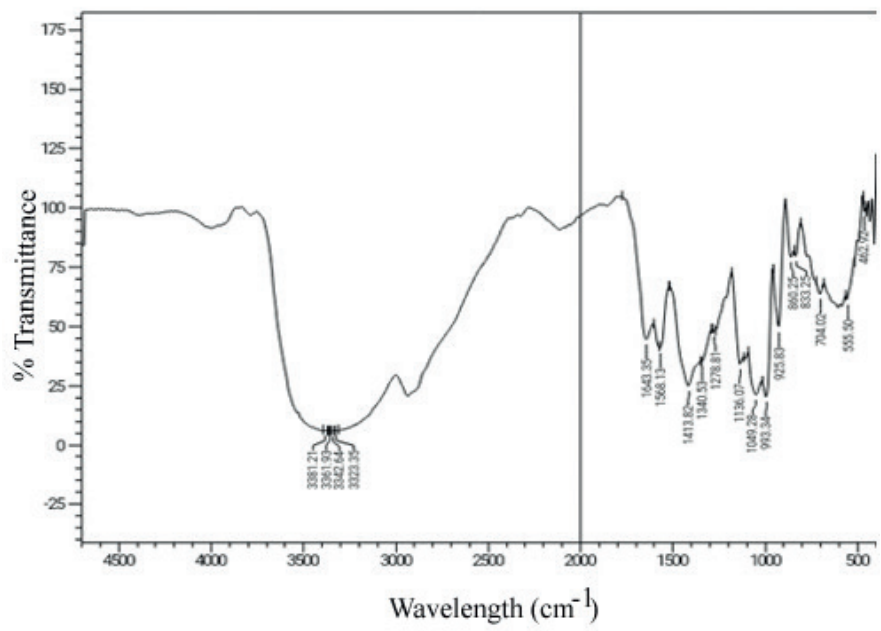

Figure 4: FTIR of unfermented papaya fruit pulp.
Alcohol content of papaya was found to be increasing during the course of fermentation. It was estimated as $3.01 \%$ on the 5 th day and increased to $10.11 \%$ on the final day (Fig. 2). Initially, the organism grows rapidly utilizing the sugar present in the substrate provided. As the process of fermentation proceeds, the percentage of alcohol increases. This increased alcohol concentration leads to a decline in the number of organisms [18]. The work done showed that papaya can be effectively used for making wine with good characteristics that provide health benefits.

\section{CONCLUSION}

Good quality wine was produced from ripe papaya fruit pulp using $S$. cerevisiae. The wine had good flavor, color, taste, and odor characteristics as well. No chemical preservation was required for the papaya wine. Further research is still required to comment on the shelf life of this wine. The different parameters analyzed in the present study will help to produce good quality wine and, therefore, it is expected that by using these parameters, the quality of wine can be improved during large-scale production.

\section{ACKNOWLEDGMENT}

The authors would like to thank the Director, K.V.M. College of Science and Technology, Cherthala, for providing necessary facilities for conducting this research work.

\section{REFERENCES}

1. Krishna KL, Paridhavi M, Patel JA. Review on nutritional, medicinal and pharmacological properties of Papaya (Carica papaya Linn.). Nat Prod Rad 2008;7(4):364-73.

2. Marotta F, Weksler M, Naito Y, Yoshida C, Yoshioka M, Marandola P. Nutraceutical supplementation: Effect of a fermented papaya preparation on redox status and DNA damage in healthy elderly individuals and relationship with GSTM1 genotype. Ann N Y Acad Sci 2006;1067(1):400-7.

3. Emmanuel IO, Odoyo O. Studies on wine production from pawpaw (Carica papaya). J Brew Distilling 2011;2(4):55-61.

4. Maragatham C, Panneerselvam A. Standardization technology of papaya wine making and quality changes in papaya wine as influenced by different sources of inoculums and pectolytic enzyme. Adv Appl Sci Res 2011;2(3):37-46.

5. Kunkee RE. Selection and modification of yeasts and lactic acid bacteria for wine fermentation. Food Microbiol 1984;1(4):315-32.

6. Ajit EJ, Dominic D, Farook F, Promod A, Kumar BMS, Blesy VJ, et al. Preparation of wine from fruits of Musa accuminata and Ananas comosus; its physico- chemical analyses and sensory evaluation. Integr Food Nutr Metab 2018;5(6):1-5.

7. Ranganna S. Handbook of analysis and quality control for fruit and vegetable products. Tata McGraw-Hill Publishing Company, New Delhi, India, pp 124-5, 1986.

8. Harborne JB. Phytochemical methods: a guide to modern techniques of plant analysis. 2nd edition, Chapman and Hall, London, UK, pp 54-84, 1998.

9. Dias DR, Duarte WF, Schwan RF. Methods of evaluation of fruit wines. Science and Technology of Fruit Wine Production. Academic Press, Cambridge, MA, pp 227-52, 2017.

10. Swami SB, Thakor NJ, Divate AD. Fruit wine production: a review. J Food Res Technol 2014;2(3):93-100.

11. Amerine MA, Amerine MA. Wine production technology in the United States. ACS Symposium Series. American Chemical Society, Wasington, DC, pp 45-57, 1981. 
12. Okafor N. Modern industrial microbiology and biotechnology. Science Publishers, Enfield, NH, pp 263-308, 2007.

13. Satav PD, Pethe AS. Effect of $\mathrm{pH}$ on physicochemical parameters of wine produced from banana. Int J Curr Microbiol Appl Sci 2016;5(2):608-13.

14. Berry CJJ. First steps in wine making. GW Kent Inc., Ypsilanti, MI, p 235, 2000

15. Clemente-Jimenez JM, Mingorance-Cazorla L, Martínez-Rodríguez S, Heras-Vázquez FJL, Rodríguez-Vico F. Influence of sequential yeast mixtures on wine fermentation. Int J Food Microbiol 2005;98(3):301-8.

16. Duarte WF, Dias DR, Oliveira MJ, Teixeira JA, Silva JBDA, Schwan RF. Characterization of different fruit wines made from cacao, cupuassu, gabiroba, jaboticaba and umbu. LWT-Food Sci Technol 2010;43(10):1564-72.

17. Olson JA. Carotenoid, vitamin A and cancer. J Nutr 1986;116(6):112730 .
18. Reddy L, Reddy O. Production, optimization and characterization of wine from Mango (Mangifera indica Linn.). Nat Prod Rad 2009;8(4):426-35.

\section{How to cite this article:}

Cholassery S, Krishna V, Sreethu VS, Shabnam SR, Vandana

R, Lisha CD, Sabu KR, Rajesh BR, Chandran RP. Analysis of physicochemical and sensory parameters of wine produced from Carica papaya. J Appl Biol Biotech 2019;7(05):74-78. 